\title{
The Roles of Language Shift in English Language Teaching (A Case Study in the Class of Grammar III in the English Department in Universitas Galuh Ciamis)
}

\author{
R. Bunga Febriani \\ Universitas Galuh Ciamis \\ bunga.febriani@gmail.com
}

\begin{abstract}
This study emphasizes the use of language shift in the English language teaching classroom. Language shift is a common phenomenon in multilingual conversations, in this case, in the teaching and learning process in language classrooms. The purposes of the study are to find out the use and the roles of language shift in EFL classrooms, how the roles contributed to the Teaching English as Foreign Language in the EFL, and how the language shift affects the process of teaching and in the EFL classroom. The study employed a qualitative approach by using interview and classroom observations as the instruments of the research. The study was a case study in the teaching and learning process of Grammar III to the second-grade students of English department in Universitas Galuh Ciamis. The findings of the study revealed that using language shift while learning and teaching English is useful in the process of teaching and learning English as a foreign language, in this case in the subject of Grammar III subject; and that code-switching as one of the kinds of language shift is necessary and inevitable in language classrooms.
\end{abstract}

\author{
ARTICLE HISTORY \\ Received 18 April 2017 \\ Accepted21 August 2017
}

\section{KEYWORDS}

Language shift; codeswitching; and ELT.

\section{Introduction}

Language shift in a language classroom is usually used as a way that helps the teacher explain the materials more clearly to the students. The kind of language shift used by the teacher is code-switching. Code-switching, to oppose the term with the other term of language shift, code mixing, is the kind of language shift which occurs by intention, in order that, in the classroom context, the teacher could explain the material more clearly.

Code-switching and code-mixing are the terms in sociolinguistics which refer to the use of more than one language which is combined in different ways. Code mixing means the use of more than one language at once, or in other words, codemixing is emphasized on hybridization. The term code-switching is emphasized on the movement from one language to another. As McArthur (1998) explained that mixing and switching probably occur to some extent in the speech of all bilinguals so that there is a sense that a person is capable of using two languages.

There are four essential types of switching. The first type of switching is Intersentential switching. This kind of switching occurs outside the sentence or the clause 
level. The second type is Intra-sentential switching, which occurs within a sentence or a clause. The next type of switching is Tag-switching. This is the switching of either a tag phrase or a word. The last type of switching is Intra-word switching, which occurs within a word itself.

Some researchers have described the use of language shift in language classrooms, especially in the EFL classrooms. Kamisah and Misyana (2011) in their study of content-based lectures found that code-mixing and code-switching served some functions such as signaling topic change, giving and clarifying the explanation, enacting social relationships and aggravating and mitigating messages. The influence of science and technology has also contributed to the code mixing and the codeswitching behavior in the classroom.

Code-mixing and code-switching are often interchangeably used. One of the differences of the terms lies in the purpose of using which kind of language shift in one context and another. Code-switching is a kind of language shift which occurs with the intention of the speaker, or on purpose. The use of code-switching is usually by conscious awareness, in other words, the speaker uses code switching intentionally and consciously. On the other hand, code mixing occurs not by purpose, and the speaker usually uses code mixing unconsciously. The code-mixing phenomena occur as a result of the speaker's incompetency in using language. By considering this, it can be inferred that the kind of language shift used by the teacher in the classrooms is code-switching because the teacher (the speaker) alternates the two or more languages in giving instructions or materials intentionally and consciously.

\section{Code Switching in EFL Classrooms}

As mentioned previously, the kind of language shift called code-switching in linguistics belongs to the field of Sociolinguistics. Code-switching occurs when a speaker alternates between two or more languages in conversation. Wardhaugh (2006) observed that particular dialect or language that a person chose to use on any occasion was a code or a system used for communication between two or more parties. People are required to select a particular code whenever they speak, and they may also decide to switch from one code to another or to mix codes even within short utterances. Speakers practice code-switching when they are each fluent in both languages.

Some researchers categorized code-switching to the various rules. Gumperz (1982) classified code-switching into two types, situational and metaphorical type. Situational code-switching refers to the switches that occur in a particular social context. Meanwhile, metaphorical code switching marks a stylistic contrast.

Code-switching is found in EFL classrooms because in the classrooms the switches between English and the first language or the mother tongue usually occur. 
Code-switching between English and the first language occurs as a conversational strategy to establish or maintain group boundaries so that the code-switching in the language classroom is used partly to create interpersonal relationships as Gysels (1992) explained that code-switching might be used to achieve two things: to fill a linguistic gap, or for other multiple communicative purposes.

\section{Grammar III Subject}

Grammar III is a subject which belongs to the necessary language skills taught to the students at the second grade of the English Department at the Faculty of Teacher Training and Educational Sciences in Universitas Galuh Ciamis. Grammar or the English structure is one of the basic language skills in English.

\section{Problem Statements}

The paper attempts to discuss the use and the roles of language shift in EFL classrooms, especially in the Grammar III classroom of the English Department in Universitas Galuh Ciamis, and how the roles contributed to the Teaching English as Foreign Language in the EFL classroom. In this study, the writer also discusses the effects of language shift on the teaching and learning process in the EFL classroom. The discussion centers on the following questions, namely:

1. How is the language shift in English Language teaching of Grammar III subject in the selected language classroom utilized?

2. What are the roles of the language shift in English as Foreign Language (EFL) classrooms according to the teachers and the students in the process of teaching and learning Grammar III subject?

3. How do the roles contribute to the teaching English as a foreign language in EFL classrooms?

4. How does the language shift affect the process of teaching and learning in the EFL classrooms?

\section{Research Methodology}

This study employed a qualitative method. The qualitative method emphasizes describing in-depth and detail of a particular activity, situation, field, behavior of people and the field (Fraenkel and Wallen, 2012). The study focused on the use and the roles of language shift in EFL classrooms, and also on how the roles contribute in the English language teaching in EFL classrooms. Like the instruments in conducting the study, the writer used questionnaires to elicit responses from respondents. According to Best and Khan (1986), in a qualitative study, interviews may yield the advantage that by building rapport with the interviewees, the interviewer can get 
some confidential information, on which they might be reluctant to express through writing. Classroom observation was also carried out as the instrument used in collecting the data as Dornyei (2007) claimed that classroom observations provide more direct information than self-reported focus. In this study, the writer played the role of the observer and also as the teacher, thus in this study, the writer took part as a participant observer.

Meanwhile, this study was designed as a case study. The case study was expected to capture the complexity of a single case and the methodology that can be developed in a particular field. The case study was not only applied in social sciences such as psychology, sociology, anthropology, and economics, but also practiceoriented fields such as environmental studies, social work, education, and business studies (Johannson, 2003: 2). In this study, a case study is used to capture the use of the language shift in the teaching of Grammar III to the class II E in the English Department at the Faculty of Teacher Training and Educational Sciences in Universitas Galuh Ciamis.

Research is not possibly completed without the population and sample. Both of them are essential aspects of conducting a study. "Population is the larger group which one hopes to apply the results and sample to the small group which applies the information" (Fraenkel and Wallen, 2012). The population of this study was the students of the second grade of the English Department of the Faculty of Teacher Training and Educational Sciences in Universitas Galuh Ciamis. Meanwhile, the sample was limited to one class of the second-grade students, namely the Class E (II E students).

The population in this study involved the lecturers, three including the writer herself as a participant observer, who taught the subject of Grammar III at the English Department in Universitas Galuh Ciamis, and the second-grade students who joined the subject of grammar III of the same institution. Meanwhile, as the sample of the study, the writer has asked for the agreement to be interviewed to two lecturers who taught Grammar III in the academic year of 2014 as peer lecturers, and the students of II E as the participants of the study.

As the data collection, the data for this study were collected through interview and participant observation. The interviews were conducted to two other teachers/lecturers who taught Grammar III in the second-grade classrooms in the English department. The questions given to the lecturers are: (1) What language(s) they usually use during the teaching of Grammar III and why they use the language(s)? (2) Do the lecturers make use of the language shift? (3) If they do, why do they use the language shift? (4) What roles does the language shift play in the teaching and learning process of Grammar III? (5) How do the roles contribute to teaching English as a foreign language in the subject of Grammar III? Moreover, (6) what are the effects of using language shift as a communicative strategy in the teaching of Grammar III in the classroom? 
Meanwhile, the pupils' were questioned about their preferences for or against the language shift and the reasons for their preference.

\section{Findings and Discussion}

The first research question posed in this study is how the language shift in English Language teaching of Grammar III subject in the selected language classroom is utilized? The languages used in the classrooms of Grammar III at the English department in Universitas Galuh Ciamis play essential roles in the process of teaching and learning in the language classroom, especially in a classroom in which the students are not the native speakers of English.

Based on the writer's observation while doing the teaching in the language classroom, language shift using code-switching was often utilized when explaining the materials to the students in the process of teaching and learning of Grammar III subject to the students. The writer finds it necessary to switch codes when teaching English in the language classroom. The use of code-switching is necessary and inevitable since some students in II E classrooms still lack of English language skills. Most of them might understand well when listening to the teacher's explanation. However, they found it quite difficult when they had to give a long or detailed answer, or when they wanted to give responses in long sentences. Thus, the language shift using code-switching often occurred or was used in the Grammar III classroom.

According to the result from the interviews with the two lecturers teaching Grammar III in the academic year of 2014 at the English Department in Universitas Galuh Ciamis, all of the interviewees confirmed that they usually use the mixture of English and Bahasa Indonesia, and sometimes Sundanese language as most of the students' mother tongue, in the process of teaching and learning Grammar III subject. Their consideration is mostly in order that the students can understand the explanation given by them. Grammar as one of the necessary skill in the English language needs thorough understanding unless the students get disoriented and unable to catch up with the future materials.

The second research question is what are the roles of the language shift in English as Foreign Language (EFL) classrooms according to the teachers and the students in the process of teaching and learning Grammar III subject? Language shift in teaching language classrooms is undoubtedly important for the success of the goal of the teaching and learning process of English, in this case in the process of teaching and learning Grammar III. One of the roles of language shift using code-switching in language classrooms was that it helped the students understand the materials being given or taught or explained better. Since the members of the language classroom did not come from native-speaker of English environment, the students still found it difficult to understand the concepts in grammar if it was being taught only in English. 
The lecturers also indicated some other roles of language shift using code-switching, as elaborated by Jogede (2012). According to Jogede (2012), there are some roles of language shift in teaching the language classrooms, namely: as (1) Repetition, (2) Ease of Expression, (3) elaboration, (4) explanation of unfamiliar words, (5) emphasis, (6) asking for explanation, (7) giving directives, (8) addressee specification, and (9) showing emotion.

The first role of language shift is repetition. In repetition, the teacher directly translated each sentence they uttered. The second role of language shift is as ease of expression which occurs when the students seemed not to understand the teacher's explanation. The teacher started the lesson in the medium of English. Since the students did not show any sign of comprehension, the teacher switched to Bahasa Indonesia. The third role is as elaboration, which occurred when additional information or details on a topic were added in the mother tongue of the students. The fourth role is to explain unfamiliar words. This role occurred when the teacher concerned for vocabulary or expressions that the students were not familiar, she/he switched the code or used the language shift through code-switching. The next role is to give emphasis or stress a point in the alternate language. The role of language shift to ask for explanation occurred when the pupils negotiated conversational involvement while seeking explanation during the lesson. The next role of language shift is to give directives. For example, as the lesson was about to start, the teacher discovered that there was no marker and instructed a student to get some markers from the next door class. Addressee specification is another role of language shift. In this role, the teacher's switches were mostly used for clarifying the meaning of certain concepts and helping the students to understand what is taught since the students could not learn in the medium of English. The last role of language shift is to show emotion.

The third research question is how do the roles contribute to the teaching English as a foreign language in EFL classrooms? The finding showed that the roles of the language shift give a significant contribution to the success of the teaching and learning activity of the subject Grammar III. The roles of language shift give both students and the teacher great opportunity to be flexible in order that the goal of the teaching and learning English as a foreign language in Grammar succeed successfully.

The finding from the students' interview showed that the use of language shift utilizing code-switching in the teaching of Grammar III is beneficial and give many advantages when learning the subject. The students were questioned about their preferences for or against the language shift and the reasons for their preference. The result of the interview to the students revealed that the students prefer for the language shift in the teaching and learning process in the classroom. By using the language shift, the students were given chances to use the language with which they feel most comfortable and have greater competence. The result also indicated that the 
students with a significant degree of bilingual communicative competence were those who most frequently used code-switching as a strategy to meet their conversational goals and to communicate with their peers.

The study has shown enough evidence to support theory that using language shift while learning and teaching English is useful in the process of teaching and learning English as foreign language, in this case in the subject of Grammar III subject; and that code-switching as one of the kinds of language shift is necessary and inevitable in language classrooms. 


\section{References}

Dornyei, Z. (2007). Research Methods in Applied Linguistics. Oxford. Oxford University Press.

Fraenkel, J.R., Wallen, N.E., Hyun, H.H. (2012). How to Design and Evaluate Research in Education eight edition. New York: McGraw-Hill

Gumperz, J. (1982). Discourse Strategies. Cambridge. Cambridge UP.

Gysels, M. (1992). French in Urban Lubumbashi Swahili: Code Switching, borrowing, or both? The Journal of Multilingual and Multicultural Development. 13(1-2), 41-45

Jogede, Olusegun. O. (2012). Roles of Code-Switching in Multilingual Public Primary Schools in Il-Ife, Nigeria. American Journal of Linguistics, 1(3):4046.

Johansson, R. (2003). Case Study Methodology, The International Conference "Methodologies in Housing Research." Royal Institute of Technology in Cooperation with the International Association of People Studies. Stockholm.

Kamisah, A., \& MIsyana, S.H. (2011). Code-switching and code-mixing of English and Bahasa Malaysia in Content-Based Classrooms: Frequency and Attitudes. The Linguistics Journal, 5(1), 220-247, Universiti Teknologi Mara Pahang.

Best, J.W. \& Khan, J.V. (1986). Research in Education, $5^{\text {th }}$ ed... New Jersey. Prentice Hall.

McArthur, Tom. (1998). "Code Mixing and Code-Switching" Concise Oxford Companion to the English Language. encyclopedia.com

Wardhaugh, Ronald. (2006), An Introduction to Sociolinguistics, fifth edition. Blackwell Publishing Ltd. The United States of America. 
49 | VISION: JOURNAL FOR LANGUAGE AND FOREIGN LANGUAGE LEARNING

\section{Teacher's Interview}

1. What language(s) they usually use during the teaching of Grammar III and why they use the language(s)?

2. Do the lecturers make use of the language shift?

3. If they do, why do they use the language shift?

4. What roles does the language shift play in the teaching and learning process of Grammar III?

5. How do the roles contribute to teaching English as a foreign language in the subject of Grammar III?

6. What are the effects of using language shift as a communicative strategy in the teaching of Grammar III in the classroom?

The questions were adapted from Jogede's work (2012). 